\title{
Identification of Different Sites of Expression for spo Loci by Transformation of Bacillus subtilis
}

\author{
By HERMINIA DE LENCASTRE* AND PATRICK J. PIGGOT \\ Division of Microbiology, National Institute for Medical Research, \\ Mill Hill, London NW7 $1 A A$
}

(Received 27 February 1979)

\begin{abstract}
Asporogenous mutants of Bacillus subtilis were rendered capable of forming heat-resistant spores by transformation with wild-type $\left(s p o^{+}\right)$DNA at, or near, the start of sporulation. For several mutants up to about $50 \%$ of the colonies derived from heat-resistant spores, formed as a result of the transformation, remained genetically asporogenous (spo). This was thought to indicate that the genome of the mother cell, but not that of the forespore, was transformed to $\mathrm{spo}^{+}$and that correct expression of the spo locus in the mother cell was sufficient for spore formation. At the end of the process the mother cell was destroyed, leaving a mature heat-resistant spore that was genetically asporogenous. It is concluded that the loci spoIIID, spoIVA, spoVB and spoVE are expressed in the mother cell. For one mutant more than $99 \%$ of the colonies derived from heat-resistant spores were genetically $s p o^{+}$. It is concluded that the locus involved, spoVA, had to be expressed in the forespore. Thus different sporulation-specific loci are expressed in the mother cell and in the forespore. The loci expressed in the mother cell are expressed in one cell type so that another cell type, the forespore, can develop into a heat-resistant spore.

Other unselected donor markers could be introduced into the recipient during transformation provided high concentrations of DNA were used. The frequency of congression was the same for spo survivors as for $s p o^{+}$survivors. This implies that there was no correlation between the DNA strand into which the selected $s p o^{+}$and the unselected donor markers integrated.
\end{abstract}

\section{INTRODUCTION}

Formation of bacterial (endo)spores is a type of cellular differentiation. It occurs as a response to nutrient starvation. During the process bacilli undergo an asymmetric division. The smaller cell that results, the forespore, is gradually engulfed by the larger cell, the mother cell. The forespore develops into the heat-resistant endospore (Fitz-James \& Young, 1969) which appears some $5 \mathrm{~h}$ after the asymmetric division. At, or after, this time the mother cell lyses. Thus, for several hours there are two cell types involved in the differentiation, the mother cell and the forespore. Both contain a copy of the chromosome, and there is active transcription of the chromosome in both cell types (Ryter et al., 1966a; Ryter \& Whitehouse, 1978).

The different fates of the mother cell and the forespore would suggest that different genes are being transcribed. This supposition is supported by biochemical characterization which has established that the constituents of the two cell types differ considerably (Andreoli et al., 1973; Eaton \& Ellar, 1974; Singh et al., 1977; Fujita et al., 1977). We were interested in identifying which genes are required in each cell type. In particular, we wished to identify the site of expression of various spo loci, many of which are associated with stages

* Permanent address: Grupo de Genética Molecular, Instituto Gulbenkian de Ciência, Oeiras, Portugal. 
Table 1. Strains of B. subtilis used

\begin{tabular}{ccc} 
Strain no. & \multicolumn{1}{c}{ Genotype } & $\begin{array}{c}\text { Isolation no. of } \\
\text { original } \\
\text { spo mutant* }\end{array}$ \\
SL10 & spo phe-12 trpC2 & - \\
SL11 & spoVB91 phe-12 trpC2 & 91 \\
SL13 & spoIVC23 trpC2 & E31 \\
SL14 & spoIIIE36 trpC2 & NG1.67 \\
SL16 & spoVE85 trpC2 & 85 \\
SL17 & spoVA89 trpC2 & 89 \\
SL49 & spoIVA67 trpC2 & NG17.23 \\
SL50 & spoIVD92 trpC2 & 92 \\
SL52 & spoIIID83 trpC2 & $83 \mathrm{U}$ \\
SL62 & spoIIIA53 trpC2 & NG12.5 \\
SL63 & spoIIIB2 trpC2 & A3 \\
SL491 & spoVB91 trpC2 & 91 \\
SL617 & spoIIG55 leuA8 tal-1 & NG12.12 \\
JH642 & spo ${ }^{+}$phe-1 trpC2 & - \\
& $*$ As listed by Piggot \& Coote (1976).
\end{tabular}

of sporulation after the asymmetric division (Piggot \& Coote, 1976). Our approach has been to transform asporogenous (spo) mutants of Bacillus subtilis 168 with wild-type $\left(s p o^{+}\right)$DNA so as to make one chromosome in the sporangium wild-type, leaving one chromosome mutant, and then study the subsequent sporulation of such transformants.

During transformation of $B$. subtilis a single strand of donor DNA integrates into the recipient chromosome, forming a heteroduplex (Dubnau, 1976). For spore formation there is an obligatory period of DNA synthesis after the start of sporulation in which most of the chromosome needs to be replicated (Mandelstam et al., 1971; Dunn et al., 1978). This replication is completed before formation of the asymmetrically sited spore division septum (Ryter \& Aubert, 1969). Thus, transformation of spo mutants with $s p o^{+}$DNA at, or just before, the start of sporulation could lead to one chromosome of the sporangium being mutant and one wild-type for the spo locus. The wild-type allele could thus segregate into the mother cell or the forespore. If correct expression of the spo locus is needed in the mother cell and not the forespore, it should be possible to obtain mature spores even though the genotype of the forespore, and hence of the mature spore, remained mutant. If correct expression is required in the forespore, then all the spores produced should be wild-type for the spo locus. Thus production of genetically asporogenous spores could be taken to indicate expression of the spo locus in the mother cell, whereas production of spores that were exclusively $s p^{+}$would imply expression in the forespore.

This argument only applies to loci that are expressed after the asymmetric division. Consequently, the study is largely limited to spo mutations that cause blocks at stage III, or later, of sporulation. It seemed reasonable to assume that the corresponding spo loci were expressed after formation of the spore septum. Detailed consideration of the importance of this assumption, and of possible alternative explanations, is given in the Discussion.

A preliminary account of part of this work was given at the VIIth International Spores Conference at Madison, Wisconsin, in October 1977 (Piggot, 1978).

\section{METHODS}

Strains. These were derivatives of Bacillus subtilis 168 trpC2. A trp transformant of B. subtilis 168 is referred to as the wild-type. Strain JH642 was kindly provided by Dr J. A. Hoch. Strains SL617 (trivial name 55.1) and SL491 (previously 91) have been described previously (Piggot \& Taylor, 1977; Hranueli et al., 1974). Strains SL10 and SL11 were constructed by transferring the phe-12 mutation into SL491 by congression, using the sporulation/transformation system (Piggot \& de Lencastre, 1978). All other strains 
were constructed by transforming SL10 with spo phe ${ }^{+}$DNA, selecting for $p h e^{+}$transformants, and screening for introduction of the spo character by congression. The strains used are listed in Table 1. Strains were stored as freeze-dried cultures. The phenotypes corresponding to the different symbols are: unable to sporulate, spo; requirement for phenylalanine, phe; requirement for tryptophan, trp; requirement for leucine, leu; resistance to $\beta$-thienylalanine, tal. The nomenclature of spo loci is that introduced by Piggot $\&$ Coote (1976). The designation of the sporulation stages reached by spo mutants is similar to the system of Ryter et al. (1966b): 0, spore septum not formed; II, spore septum formed; III, forespore free within mother cell; IV, forespore has primordial germ cell wall and/or cortex, but no coat; V, coat layers have been formed around the forespore.

Media. The growth, sporulation and exhaustion media used in sporulation/transformation experiments were based on those described by Ramaley \& Burden (1970) for replacement sporulation. The basic medium contained (in 11 final vol., adjusted to pH 7.2) $0.33 \mathrm{ml} 85 \% \mathrm{H}_{3} \mathrm{PO}_{4}, 1 \mathrm{~g} \mathrm{MgSO}_{4} .7 \mathrm{H}_{2} \mathrm{O}, 0.4 \mathrm{~g} \mathrm{NaCl}, 0.4 \mathrm{~g}$ $\mathrm{KCl}, 25 \mathrm{mg} \mathrm{Fe}\left(\mathrm{NH}_{4}\right)_{2}\left(\mathrm{SO}_{4}\right)_{2} \cdot 6 \mathrm{H}_{2} \mathrm{O}, 10 \mathrm{mg} \mathrm{CaCl}$ and $6 \mathrm{mg} \mathrm{MnSO} 4 \cdot \mathrm{H}_{2} \mathrm{O}$. Solutions of $\mathrm{MgSO}_{4}$ and $\mathrm{CaCl}_{2}$ were sterilized separately. In addition, growth medium contained $20 \mathrm{~mm}$-glucose and $50 \mathrm{~mm}$-sodium glutamate, sporulation medium contained $10 \mathrm{~mm}$-sodium glutamate and no glucose, and exhaustion medium contained $3 \mathrm{~mm}$-glucose and $10 \mathrm{~mm}$-sodium glutamate. Where necessary media were supplemented with $10 \mu \mathrm{g}$ tryptophan $\mathrm{ml}^{-1}, 100 \mu \mathrm{g}$ phenylalanine $\mathrm{ml}^{-1}$ and $100 \mu \mathrm{g}$ leucine $\mathrm{ml}^{-1}$. All other media have been decribed previously (Piggot, 1973).

Sporulation/transformation experiments. Bacteria were inoculated into growth or exhaustion medium from single colonies on fresh nutrient agar. Cultures were grown overnight and then diluted (if necessary) into the same medium so as to ensure exponential growth at the end of the day. From the exponentially growing culture, dilutions were again made into the same medium so as to ensure exponential growth the following morning. This culture was then used for sporulation/transformation experiments.

Cultures were incubated at $37^{\circ} \mathrm{C}$ in conical flasks such that the culture occupied not more than $12.5 \%$ of the flask volume. Media were prewarmed to $37^{\circ} \mathrm{C}$ before use. Flasks were shaken on a reciprocal shaker at 75 to 90 strokes $\mathrm{min}^{-1}$. Bacterial growth was monitored by measuring the $A_{600}$ with a Unicam SP600 spectrophotometer. Absorbance was converted to bacterial density by means of a standard calibration curve.

To obtain sporulation by the replacement system, exponentially growing bacteria were harvested at a density of between 0.05 and $0.15 \mathrm{mg}$ dry wt $\mathrm{ml}^{-1}$ either by centrifugation or by filtration. They were then resuspended directly in the sporulation medium and incubation was continued. DNA was added at the time of resuspension and was used at $5 \mu \mathrm{g} \mathrm{ml}^{-1}$ unless otherwise stated. This was a saturating concentration and high frequencies of congression were obtained. DNA was inactivated with pancreatic DNAase (Sigma, $\left.100 \mu \mathrm{g} \mathrm{ml}^{-1}\right) 30 \mathrm{~min}$ after its addition to cultures.

Cultures were incubated for 16 to $20 \mathrm{~h}$ after the time of resuspension (replacement system) or after the end of exponential growth (exhaustion system), and then portions were heated to $85^{\circ} \mathrm{C}$ for $20 \mathrm{~min}$ to select heat-resistant spores. Survivors were scored by incubating samples on nutrient agar plates for $48 \mathrm{~h}$ at $42{ }^{\circ} \mathrm{C}$. At this time phenotypically $\mathrm{Spo}^{+}$and $\mathrm{Spo}^{-}$colonies could generally be distinguished by opacity and pigmentation with the aid of a dissecting microscope using transmitted light (4/200 Stereo, Vision Engineering, Send, Woking; or M5A, Wild Heerbrugg U.K., Chatham, Kent). The distinction was always confirmed by examination with a phase-contrast microscope (M20, Wild). When the initial distinction between colony types was not clear, notably with $s p o V A 89$ and $s p o^{+}$colonies or when there were few colonies on a plate, individual colonies were picked, resuspended in Spizizen (1958) salts $(0.5 \mathrm{ml})$, heat-treated at $85^{\circ} \mathrm{C}$ for $20 \mathrm{~min}$, and then survivors were scored by incubation on nutrient agar. The genetic stability of survivors from the original heat treatment was confirmed by picking isolated colonies from the nutrient agar and streaking them to single colonies on fresh nutrient agar. In all cases the final phenotype, Spo- or $\mathrm{Spo}^{+}$, was the same as the initial phenotype of the colonies resulting from heat-resistant spores. It was therefore assumed to correspond to the genotype, spo or $s p o^{+}$, respectively. Spores formed as a result of transformation of an asporogenous mutant in the sporulation/transformation system are referred to as transformant spores. Depending on their genotype, they are referred to as spo transformant spores or $s p o^{+}$transformant spores.

Growth requirements of transformant spores were tested by picking colonies from nutrient agar and streaking them on to minimal agar with appropriate supplements.

$D N A$. DNA was prepared by the method of Marmur (1961). The DNA concentration was determined using diphenylamine as described by Giles \& Myers (1965). The sterility of DNA was checked for each experiment.

Inhibition of chromosome replication. Chromosome replication was inhibited with 6-( $p$-hydroxyphenylazo)uracil (HPUra; Brown, 1970, 1971). HPUra was dissolved at a concentration of $0.01 \mathrm{M}$ in $0.05 \mathrm{M}-\mathrm{NaOH}$ and used at a final concentration of $66.6 \mu \mathrm{M}$. The trace of $\mathrm{NaOH}$ added to cultures did not alter the $\mathrm{pH}$ significantly, nor did it affect transformation, sporulation or the ability of transformants to sporulate. HPUra was a gift of Dr B. Langley, Imperial Chemical Industries. 


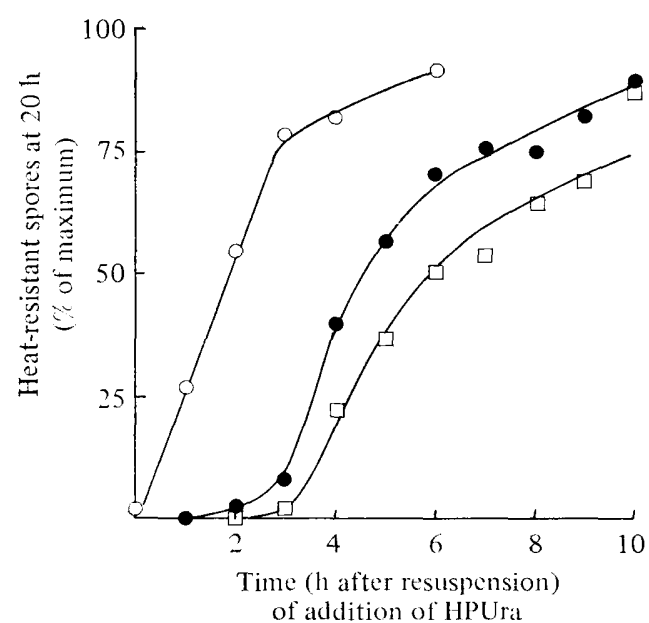

Fig. 1

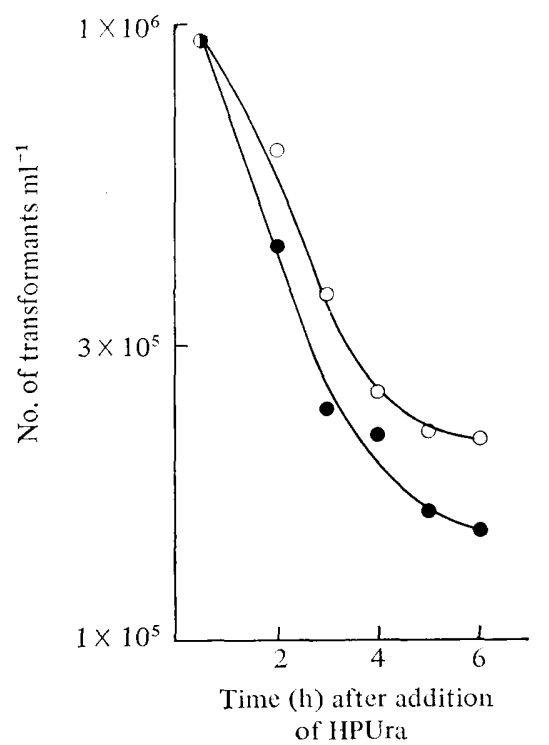

Fig. 2

Fig. 1. Effect on sporulation of inhibition of DNA synthesis by HPUra. Cultures of JH642 (spo+) and of SL11 (spoVB91) were incubated in growth medium and then transferred to sporulation medium. Strain SL11 was transformed with wild-type DNA at the time of transfer. At different times thereafter, HPUra was added. Cultures were incubated for $20 \mathrm{~h}$ after the time of transfer, and then heated to $85^{\circ} \mathrm{C}$ for $20 \mathrm{~min}$. Survivors were recovered on nutrient agar. The numbers of survivors are expressed as a percentage of the number surviving when HPUra was not added until immediately before the heat shock. O, Sporulation of JH642; O, formation of spo spores by SL11; $\square$, formation of $s p o^{+}$spores by SL11.

Fig. 2. Effect of the addition of HPUra on the transformation of strain SL11 in sporulation medium. Strain SL11 was incubated in growth medium and then transferred to sporulation medium containing wild-type DNA. At this time the culture was divided, half being incubated with HPUra and half without. After $30 \mathrm{~min}$, the DNA was inactivated with DNAase, and at intervals thereafter samples were removed and plated on minimal agar to select for $t r p^{+}$transformants. $\bigcirc$, No HPUra;, $66 \cdot 6 \mu \mathrm{M}-\mathrm{HPU}$ ra.

\section{RESULTS}

In the replacement system of Ramaley \& Burden (1970), more than $70 \%$ of the population of $\mathrm{spo}^{+}$strains formed spores. The extent of residual growth in the sporulation medium depended on the bacterial density at the time of transfer. It was generally slight, and under the conditions used here represented less than $50 \%$ increase in $A_{600}$. DNA synthesis was necessary for spore formation. Addition of HPUra, a drug that specifically inhibits DNA replication in B. subtilis (Brown, 1970), at the time of resuspension prevented spore formation by strain JH642 (Fig. 1); the few spores detected represented the basal level of spores present at the time of resuspension. The sensitivity of sporulation to inhibition by HPUra has been reported previously (Dunn et al., 1978; Leighton et al., 1975; Shibano et al., 1978). Addition of HPUra at different times after resuspension showed a progressive escape of sporulation from inhibition by the drug, so that by $3 \mathrm{~h}$ more than $75 \%$ of the population had become insensitive. The escape curve was similar to that obtained by Dunn et al. (1978), although the lag before escape started was not estimated accurately.

Auxotrophic bacteria were competent to be transformed to prototrophy throughout growth and could be transformed as late as the time of resuspension in sporulation medium. Thereafter competence dropped rapidly. Some asporogenous mutants could be transformed at the time of resuspension and these transformants could form spores. Preliminary experiments indicated that strain SL491 (spoVB91 trpC2) and its derivatives, notably SL11, were particularly good recipients for transformation of the ability to sporulate. Further, a 


\title{
Table 2. Transformation of strain SL11 at the time of resuspension in sporulation medium
}

\begin{abstract}
Strain SL11 was incubated in growth medium and then transferred to sporulation medium containing the appropriate DNA. After $30 \mathrm{~min}$, DNAase was added to each flask, and $5 \mathrm{~min}$ later a sample was removed to select for phe+ transformants. After $18 \mathrm{~h}$, cultures were heated to $85^{\circ} \mathrm{C}$ for $20 \mathrm{~min}$ and survivors were recovered on nutrient agar. Numbers of transformants are the numbers of colonies obtained from $0.2 \mathrm{ml}$ samples.
\end{abstract}

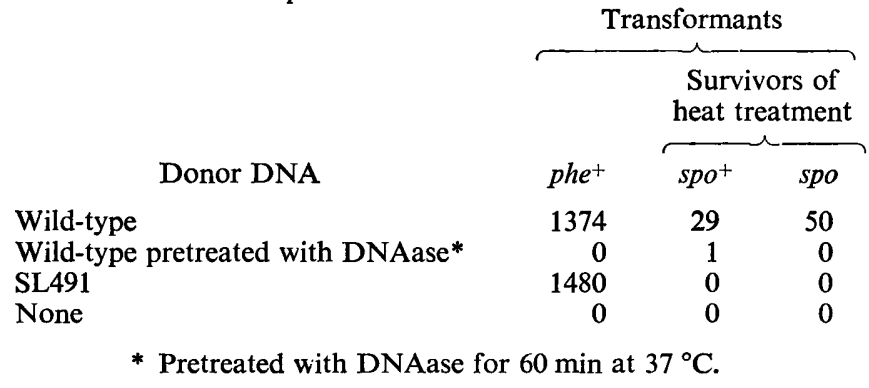

high proportion of the colonies that grew up from the resulting heat-resistant spores were genetically asporogenous (Piggot \& de Lencastre, 1978). These strains were therefore used to characterize the system in experiments where transformations were performed at the time of resuspension. The process was dependent on the use of intact DNA bearing the wildtype allele of the spoVB91 locus (Table 2); DNA bearing the spoVB91 mutation was inactive as was $s p o^{+}$DNA that had been pretreated with DNAase. The system thus had the essentials of DNA-mediated transformation.

Addition of HPUra at the time of transformation of strain SL11 with wild-type DNA did not affect the formation of $t r p^{+}$transformants (Fig. 2). In contrast it completely prevented the ability of transformants to sporulate and, indeed, addition as late as $3 \mathrm{~h}$ after the time of resuspension largely prevented the sporulation of transformants (Fig. 1).

The escape from HPUra inhibition of sporulation for SL11 transformants was delayed by 2 to $3 \mathrm{~h}$ compared with that for the wild-type (Fig. 1). This delay presumably corresponds to a latent period following transformation. Transformed bacilli are known to be latent for about $3 \mathrm{~h}$ (Nester \& Stocker, 1963), and we have observed the same latent period for bacteria transformed for auxotrophic markers in growth medium when the bulk of the population was growing exponentially. It was not possible to measure the latent period in sporulation medium accurately as there was a substantial loss of viability of $t r p^{+}$transformed bacteria under these conditions (Fig. 2). The loss of viability also prevented estimation of the extent of DNA replication in transformed bacteria. However, there was a small, but reproducible, difference in the times of escape from HPUra inhibition for the formation of spo and $s p o^{+}$transformant spores from SL11 (Fig. 1) which implied a difference in the replication pattern leading to their formation. When the initial stages of the escape from HPUra were examined, more than $80 \%$ of the spores formed were spo (Table 3). This implied that less DNA replication was required to form $s p o$ spores than $s p o^{+}$spores. As the transformed bacteria that become $s p o$ and $s p o^{+}$spores could be different, this conclusion must be tentative. It is also formally possible that the bacteria which become $s p o^{+}$spores are latent for a longer time than those which become spo spores.

Several other spo mutants transformed poorly in the sporulation medium. They transformed reasonably, although variably, for auxotrophic characters in the growth medium. However, the process of transferring newly transformed asporogenous mutants from one medium to another greatly impaired their ability to sporulate. The reason for this is not known. The transfer did not impair sporulation of the wild-type. The manipulations involved in the transfer did not affect the competence to be transformed for auxotrophic markers or the ability of newly transformed auxotrophic mutants to yield prototrophic transformants. 
Table 3. Effect of HPUra on the relative proportion of spo and spo ${ }^{+}$ transformant spores of strain SL11

Strain SL11 was incubated in growth medium and then transferred to sporulation medium containing wild-type DNA. At different times thereafter, HPUra was added. Cultures were incubated for $18 \mathrm{~h}$ after the time of transfer and then heated to $85^{\circ} \mathrm{C}$ for $20 \mathrm{~min}$. Survivors were scored on nutrient agar. Numbers of transformants are the numbers of colonies obtained from $\mathbf{0} \cdot \mathbf{2} \mathrm{ml}$ samples.

\begin{tabular}{|c|c|c|c|}
\hline \multirow[b]{2}{*}{ Treatment } & \multicolumn{2}{|c|}{ Transformants } & \multirow{2}{*}{$\frac{100 \times \text { spo }}{\left(s p o^{+}+s p o\right)}$} \\
\hline & $\mathrm{spo}^{+}$ & spo & \\
\hline None & 4090 & 2915 & 42 \\
\hline $\mathrm{NaOH}$ used] to dissolve HPUra & 3720 & 2330 & 39 \\
\hline HPUra at $0 \mathrm{~h}$ & 0 & 2 & $(100)$ \\
\hline $30 \mathrm{~min}$ & 3 & 19 & 86 \\
\hline $1 \mathrm{~h}$ & 9 & 46 & 84 \\
\hline $2 \mathrm{~h}$ & 25 & 121 & 83 \\
\hline $3 \mathrm{~h}$ & 100 & 405 & 80 \\
\hline $4 \mathrm{~h}$ & 271 & 695 & 72 \\
\hline $5 \mathrm{~h}$ & 586 & 922 & 61 \\
\hline $6 \mathrm{~h}$ & 1063 & 1502 & 58 \\
\hline $18 \mathrm{~h}$ & 3300 & 2975 & 47 \\
\hline No DNA & 0 & 0 & - \\
\hline
\end{tabular}

The exhaustion medium was introduced to overcome the problem. Even so, the number of transformant spores rarely amounted to more than $10 \%$ of the number of prototrophic transformants. This could be a consequence of several factors: the poor viability of all transformants in the sporulation medium; the particular sensitivity of potential sporulation transformants; and features of the emergence from latency that may be detrimental to spore formation. In the exhaustion medium, bacteria grew exponentially at the same rate as in growth medium up to approximately $250 \mu \mathrm{g}$ dry wt $\mathrm{ml}^{-1}$. Growth then stopped and $\mathrm{spo}^{+}$strains went on to form more than $70 \%$ spores. Use of this medium permitted investigation of the formation of transformant spo spores with transformations performed at different times before the end of exponential growth.

Strain SL16 was grown in the exhaustion medium and at intervals portions were removed and treated with wild-type DNA. Transformability for all characters varied during growth and declined as growth stopped (Fig. 3). Very few spo spores were obtained when the culture was transformed two generations before the end of exponential growth, but the proportion of spo spores relative to total spores progressively increased the nearer the culture was to the end of exponential growth when transformed, reaching a maximum of $33 \%$ (Fig. 4). Strains SL11, SL52 and SL49 behaved similarly to strain SL16. The results for SL49 are less extensive than those for the other strains as we rarely obtained cultures that were even poorly competent near the end of exponential growth. In the absence of DNA no spores of any sort were formed.

It was not possible to relate the ratio of $s p o$ to $\left(s p o+s p o^{+}\right)$transformant spores to the precise extent of DNA replication and cell division that took place between integration of the transforming DNA and formation of a spore (see above section describing the effects of HPUra). However, it seems reasonable to conclude that the less such 'residual' DNA replication, the higher the proportion of spo spores.

Strain SL17, carrying the spoVA89 mutation, gave a completely different pattern. More than $99 \%$ of the heat-resistant transformants were genetically $s p o^{+}$whenever the transformation was performed (Fig. 4). It should be emphasized that this strain was isogenic with the others except for the spo mutations in question. The interpretation of these results, to be developed in the Discussion, is that the spoVA locus has to be correctly expressed in 


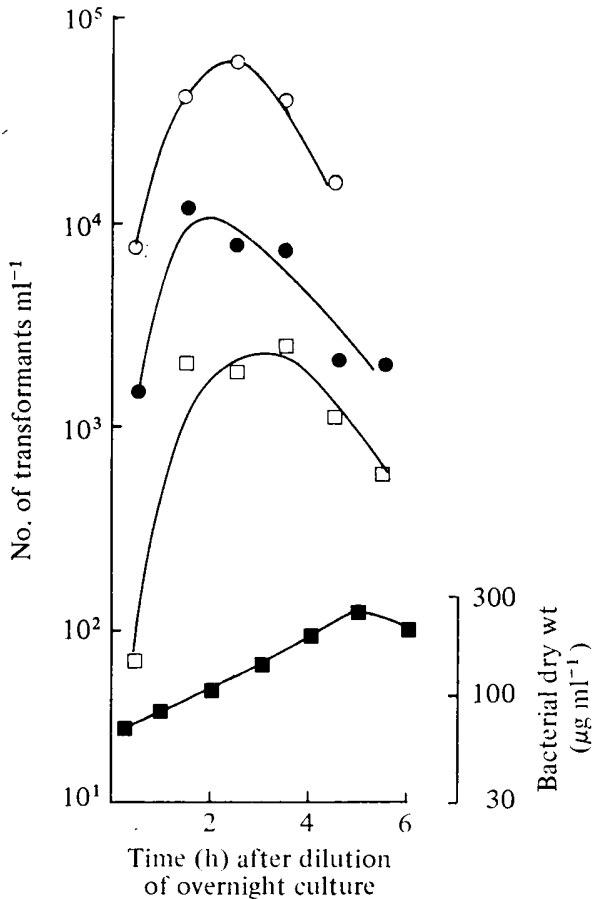

Fig. 3

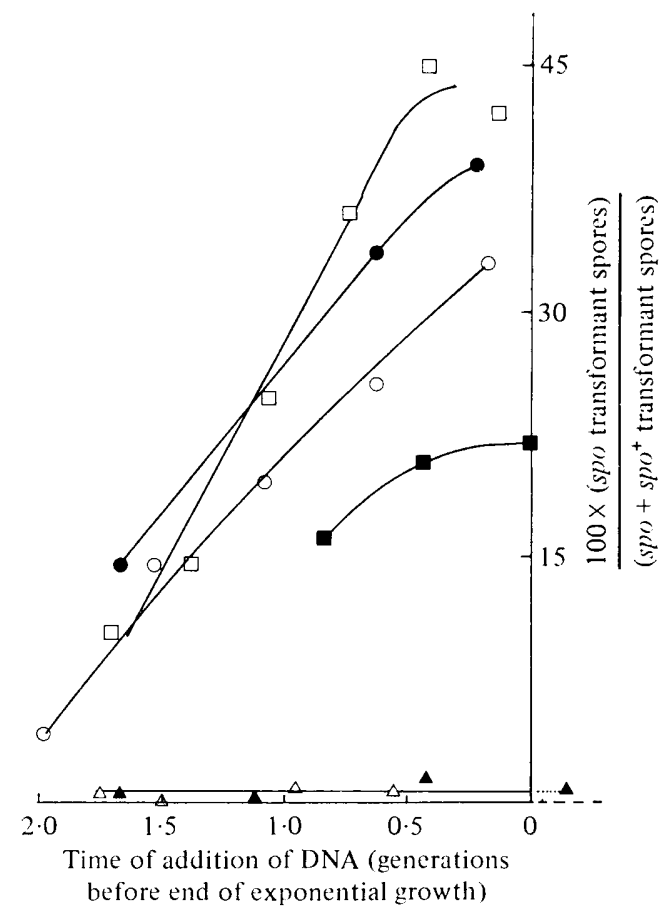

Fig. 4

Fig. 3. Transformation of strain SL16 with wild-type DNA in exhaustion medium. Strain SL16 was grown in exhaustion medium and at intervals portions $(5 \mathrm{ml})$ were transformed with wild-type DNA. After $30 \mathrm{~min}$, DNAase $\left(100 \mu \mathrm{g} \mathrm{ml}^{-1}\right)$ was added and $5 \mathrm{~min}$ later a sample $(0.1 \mathrm{ml})$ was removed to determine transformation to $\mathrm{trp}^{+}$. At $20 \mathrm{~h}$ after the end of exponential growth, portions were heated to $85^{\circ} \mathrm{C}$ for $20 \mathrm{~min}$ and survivors were recovered on nutrient agar. $\bigcirc$, trp $p^{+}$transformants; 0 , spo $o^{+}$transformant spores; $\square$, spo transformant spores; $\square$, growth curve.

Fig. 4. Proportion of spo spores amongst total transformant spores for spo mutants transformed at different times during growth. Details of the experimental procedure are in the legend to Fig. 3. For each point a minimum of 100 colonies resulting from transformant spores was counted [with the exception of the point at $0 \cdot 13$ generations for SL52 (32 spo, $43 \mathrm{spo}^{+}$colonies)]. $\bigcirc$, SL16; , SL11; $\square$, SL52; $\square$, SL49; $\triangle, \triangle$, SL17 (two experiments).

the forespore, whereas expression of the spoVE, spoVB, spoIVA and spoIIID loci in the mother cell is sufficient for spore formation.

Strains carrying the spoIVD92 mutation were highly transformable for auxotrophic markers $\left(6 \times 10^{5}\right.$ transformants $\left.\mathrm{ml}^{-1}\right)$, but could only be transformed to sporulate at very low frequencies. This was true even when the transformation was performed $5 \mathrm{~h}$ (about 3 generations) before the end of exponential growth, when a maximum of $2 \times 10^{3}$ transformant spores $\mathrm{ml}^{-1}$ was obtained. The spoIVD92 mutation was transferred into $s p o^{+}$ strains by transformation on several occasions. In each case the constructed strain showed the same behaviour. The frequency of transfer was consistent with spoIVD92 being a single mutation. One possible explanation of the result would be that the locus needs to be expressed for several generations before the start of spore formation.

The one stage II mutant tested, strain SL617, behaved in the same way as the SL11/SL16 class of strains ( $38 \%$ of the heat-resistant transformants were $s p o$ ). No experiments were performed with other stage II mutants, and no further experiments were done with SL617 because of problems in interpretation (see Discussion). 
Table 4. Transformation in exhaustion medium of the oligosporogenous strain SL62 with spo $^{+}$DNA and with DNA from a trp ${ }^{+}$derivative of SL62

Numbers of transformants are the numbers of colonies on nutrient agar obtained from $0 \cdot 2 \mathrm{ml}$ culture following heat treatment; they are the mean of two or three determinations. When no DNA was used, and when $s p o^{+}$DNA had been pretreated with DNAase $\left(60 \mathrm{~min}, 37^{\circ} \mathrm{C}\right), 22$ spo colonies were obtained from $0.2 \mathrm{ml}$ culture following heat treatment. The difference between the number of spo colonies obtained with the $s p o^{+}$donor and with the spoIIIA53 donor is referred to as $\Delta$ spo.

\begin{tabular}{|c|c|c|c|c|}
\hline \multirow{3}{*}{$\begin{array}{l}\text { Time of } \\
\text { transformation } \\
\text { (generations } \\
\text { before end of } \\
\text { exponential } \\
\text { growth) }\end{array}$} & \multicolumn{3}{|c|}{ Transformants } & \multirow{3}{*}{$\frac{100 \times \Delta \text { spo }}{\left(s p o^{+}+\Delta s p o\right)}$} \\
\hline & \multicolumn{2}{|c|}{$s p o^{+}$donor } & \multirow{2}{*}{$\begin{array}{c}\text { spoIIIA53 } \\
\text { donor } \\
\text { spo }\end{array}$} & \\
\hline & $\mathrm{spo}^{+}$ & spo & & \\
\hline $2 \cdot 32$ & 2260 & 108 & 24 & 3.6 \\
\hline 1.96 & 988 & 46 & 25 & $2 \cdot 1$ \\
\hline $1 \cdot 61$ & 833 & 119 & 20 & $10 \cdot 6$ \\
\hline 1.25 & 395 & 65 & 23 & $9 \cdot 6$ \\
\hline $0 \cdot 89$ & 369 & 85 & 25 & $14 \cdot 0$ \\
\hline 0.53 & 277 & 103 & 21 & $22 \cdot 8$ \\
\hline $0 \cdot 18$ & 340 & 108 & 22 & $20 \cdot 2$ \\
\hline
\end{tabular}

\section{Oligosporogenous mutants}

Most of the spo mutants blocked at stage III, or later, that were tested in the sporulation/ transformation system were found to be oligosporogenous to varying degrees. A few were only slightly leaky (less than one spore in $10^{5}$ bacteria) and were studied further. The strains were transformed at different times throughout growth in the exhaustion medium with wild-type DNA and with DNA bearing the spo mutation of the recipient strain. The latter set of transformations provided a control for the degree of oligosporogeny.

Strain SL62, with the spoIIIA53 mutation, gave a constant background of spo spores when transformed with DNA containing the spoIIIA53 mutation (Table 4). Transformation with $s p o^{+}$DNA gave substantially higher numbers of spo spores than the control crosses. The ratio $\Delta s p o /$ (total transformant spores) changed in a similar way to that observed for various asporogenous mutants (Fig. 4), reaching a maximum of nearly $25 \%$. There must nevertheless be some reservation in interpretation because the determinants of the degree of leakiness in oligosporogenous mutants are not understood (Piggot \& Coote, 1976).

For other oligosporogenous mutants the results for transformation during growth in exhaustion medium were not readily interpretable. In crosses with wild-type DNA the proportion of spo colonies amongst total colonies from survivors of heat treatment rarely exceeded $10 \%$ when the recipient was transformed at a reasonable frequency (indicated by the numbers of prototrophic transformants). The strains were poorly competent towards the end of exponential growth. Moreover, in companion crosses, using DNA bearing the spo mutation of the recipient, the yield of spo spores was quite variable. Thus it was not possible to make an adequate correction for the degree of oligosporogeny in crosses with $s p o^{+}$DNA where spo spores resulted. In particular it was not possible to make any meaningful estimate of the ratio of $s p o$ to $s p o^{+}$transformants in populations transformed at, or near, the end of exponential growth.

There was, however, clear indication that some spo spores resulted from $s p o^{+} \mathrm{DNA}-$ mediated transformation of these mutants. This indication was obtained from an estimate of the appearance of the donor $t r p^{+}$character in spo survivors of transformation of spo $\operatorname{trpC2}$ strains with $s p o^{+} t r p^{+}$DNA followed by heat treatment. With asporogenous mutants, about $5 \%$ of the survivors in such a cross became $\operatorname{trp}^{+}$(Table 5, mutants SL491, SL16 and SL52). There is no significant reversion of $\operatorname{trpC2}$. This phenomenon, termed congression 
Table 5. Congression of trp ${ }^{+}$amongst transformants selected for spore formation

Strains SL491, SL16 and SL52 were asporogenous; strains SL13, SL14 and SL63 were oligosporogenous. Data for oligosporogenous mutants were pooled from several crosses. The numbers of $s p o^{+}$and $s p o$ colonies tested did not reflect the relative proportions of the two colony types. Wild-type DNA was used. Strain SL491 was transformed upon transfer to the sporulation medium (replacement system); other strains were transformed in the exhaustion medium.

\begin{tabular}{|c|c|c|c|c|c|c|c|}
\hline & & & Con- & & & Cor & $\begin{array}{c}\text { Con- } \\
\text { gression } \\
(s p o)\end{array}$ \\
\hline Recipient & $\begin{array}{c}\text { spo+ } \\
\text { colonies } \\
\text { tested }\end{array}$ & $\begin{array}{l}s p o^{+} t r p^{+} \\
\text {colonies } \\
\text { present }\end{array}$ & $\begin{array}{l}\text { gression } \\
\text { amongst } \\
s p o^{+}(\%)\end{array}$ & $\begin{array}{c}\text { spo } \\
\text { colonies } \\
\text { tested }\end{array}$ & $\begin{array}{l}\text { spo trp } \\
\text { colonies } \\
\text { present }\end{array}$ & $\begin{array}{l}\text { gression } \\
\text { amongst } \\
\text { spo }(\%)\end{array}$ & $\begin{array}{c}\text { Con- } \\
\text { gression } \\
\left(s p o^{+}\right)\end{array}$ \\
\hline SL491 & 280 & 17 & $6 \cdot 1$ & 296 & 22 & $7 \cdot 4$ & $1 \cdot 2$ \\
\hline SL491* & 220 & 1 & 0.5 & 184 & 2 & $1 \cdot 1$ & - \\
\hline SL16 & 166 & 8 & $4 \cdot 8$ & 167 & 8 & $4 \cdot 8$ & $1 \cdot 0$ \\
\hline SL52 & ND & ND & - & 108 & 6 & $5 \cdot 6$ & - \\
\hline SL13 & 211 & 15 & $7 \cdot 1$ & 196 & 3 & 1.5 & 0.2 \\
\hline SL14 & 700 & 26 & $3 \cdot 7$ & 831 & 41 & $4 \cdot 9$ & $1 \cdot 3$ \\
\hline SL63 & 970 & 27 & $2 \cdot 8$ & 363 & 11 & $3 \cdot 0$ & $1 \cdot 1$ \\
\hline
\end{tabular}

ND, Not determined. $\quad * 0 \cdot 2 \mu \mathrm{g} \mathrm{DNA} \mathrm{mi}^{-1}$ was used; in other experiments $\geqslant 4 \mu \mathrm{g} \mathrm{DNA} \mathrm{ml}^{-1}$ was used.

(Nester et al., 1963), is thought to result from a second piece of DNA, carrying the trp ${ }^{+}$ marker, entering some of the bacteria that receive the $s p o^{+}$marker for which selection was made. The frequency of congression was similar for $s p o^{+}$and spo spores formed from asporogenous mutants. With oligosporogenous mutants SL14 and SL63 the frequency of congression was again similar for $s p o^{+}$and spo spores. This suggested that the majority of spo spores in both cases were, indeed, the result of transformation. With mutant SL13 the frequency of congression was much lower with spo spores than with $s p o^{+}$indicating that only some of the spo spores were the result of transformation.

\section{DISCUSSION}

We have investigated the effect of transforming asporogenous mutants of $B$. subtilis in conditions where the wild-type was starting, or about to start, spore formation. Some of the mutants could go on to form heat-resistant spores as a result of transformation with intact $s p o^{+}$DNA. These mutants fell into two classes. In the first class, as many as 30 to $50 \%$ of the colonies that grew up from the heat-resistant spores retained the asporogenous genotype of the original mutant. This class included strains with spoVB91, spoVE85, spoIIID 83 or spoIVA67 mutations. In the second class, represented by a strain with the spoVA89 mutation, more than $99 \%$ of the colonies that grew up from heat-resistant spores were genetically $s \mathrm{po}^{+}$. A number of oligosporogenous mutants were also studied, but the results obtained were generally indecisive. However, in one case, a strain with the spoIIIA53 mutation, up to $25 \%$ of the spores formed as a result of transformation were genetically spo. We interpret the results to mean that expression of the spoVB, spoVE, spoIIID, spoIVA and, probably, spoIIIA loci in the mother cell is sufficient for correct spore formation, whilst the spoVA locus must be expressed in the forespore; it is not possible to say if the spoVA locus must also be expressed in the mother cell.

Before expanding on this conclusion, possible alternative explanations of the formation of asporogenous spores need to be considered, namely, abortive transformation, strand selection, and dominance of $s \mathrm{po}^{+}$over spo in a diploid. No case of abortive transformation, i.e. transmission of an unincorporated and unreplicated linear piece of donor chromosome, is known (Nester \& Stocker, 1963; Jensen, 1968), and it is thought not to occur here. In 


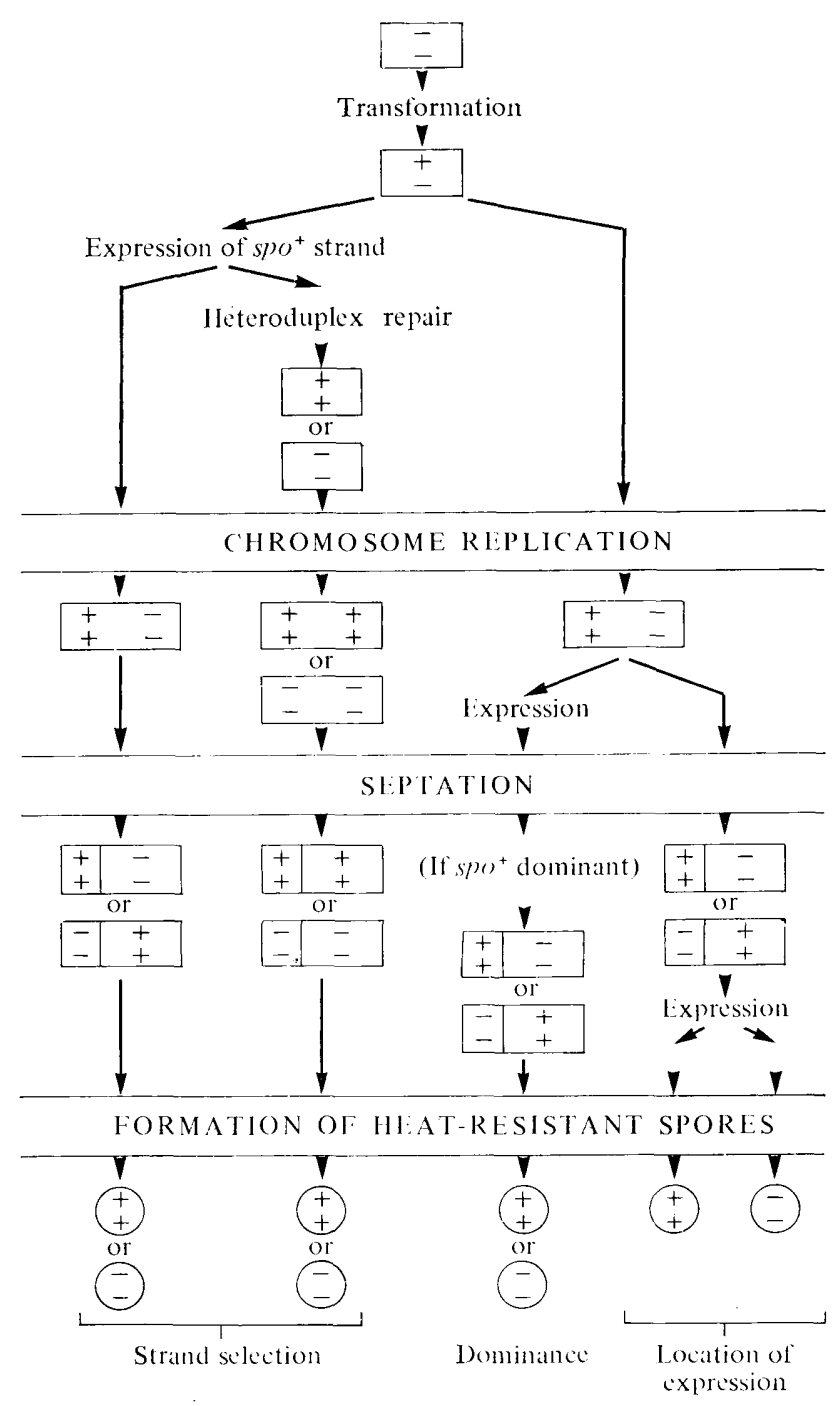

Fig. 5. Schematic representation of the possible routes by which a transformed spo mutant could form a spore. The only cases considered are those where the transformation takes place immediately before the start of sporulation. In this situation there is only one round of DNA replication between integration of transforming DNA and formation of the mature spore. Each DNA strand is represented by the genotype of the spo locus. Thus the wild-type chromosome is + , the mutant chromosome -, and the heteroduplex formed after integration of a single strand of wild-type donor DNA during transformation is \pm .

the crosses where auxotrophs were transformed to prototrophy, abortive transformation would have given rise to micro-colonies and none of these were observed.

To distinguish between the other possible explanations, it is useful to visualize the possible routes by which a transformed spo mutant could form a spo spore (Fig. 5). The only cases considered are those where there is only one round of DNA replication between the integration of the transforming DNA and the formation of mature spores; depending on the mode of spo locus expression, additional rounds of DNA replication would either eliminate or greatly reduce the possibility of forming spo spores. A single strand of donor $s p o^{+}$DNA is first integrated into the recipient genome to form a $s p o / s p o^{+}$heteroduplex. 
In one possible course of events, strand selection (Fig. 5), the $s p o^{+}$strand of the heteroduplex would be expressed, enabling the sporangium to form a heat-resistant spore. After expression, the heteroduplex could either be repaired to give back the mutant spo/spo homoduplex which would be incorporated into the heat-resistant spore or could be replicated to give $s p o / s p o$ and $s p o^{+} / s p o^{+}$homoduplexes with the spo/spo segregating into the forespore. A second course would envisage the $s p o^{+}$allele being expressed after replication but before the chromosomes were partitioned by septum formation. There is then a situation where spo and $\mathrm{spo}^{+}$chromosomes would be expressed in the same cytoplasm. If the spo allele were recessive to the wild-type, it would be possible to obtain heat-resistant spores that are genetically spo. The other possibility is that expression of the $s p o^{+}$allele need only take place in the mother cell so that it would be possible for the developing spore to retain the mutant spo allele (Fig. 5).

The critical parameters to distinguish between these possibilities are the time of spo locus expression relative to replication of the transformed locus and relative to partitioning of the chromosomes at stage II. All of the mutants used in this study were blocked at stage II or later. However, the precise times of expression of the different spo loci have not been determined, and it is possible that there is a gap between the point at which a locus is expressed and the stage reached by mutants blocked in the expression of that locus. For spoII mutants there is, therefore, some doubt as to the time of spo locus expression relative to septum formation, and so we cannot distinguish between the different possibilities (Fig. 5). The transition from stage II to stage III takes about $1 \mathrm{~h}$ at $37^{\circ} \mathrm{C}$ (Dawes et al., 1969). Consequently, for mutants blocked at stage III or later we feel reasonably confident in assuming that the mutant loci are expressed after septum formation. Thus we feel reasonably confident in concluding that correct expression of the spoVA locus must take place in the forespore whereas expression in the mother cell of the $s p o I I I D, \operatorname{spoIVA}$, spoVB and spoVE loci, and probably the spoIIIA locus, is sufficient for spore formation.

In studies of the latter group of loci, the proportion of spo transformant spores was rarely more than $50 \%$ of the total number of transformant spores. Thus it is formally possible that these loci could be expressed in either the forespore or the mother cell for successful spore formation. Alternatively, expression could be required in the mother cell and not the forespore, and the DNA of many transformants could have undergone heteroduplex repair or sufficient replication, so that the genome of both cell types had become $s p o^{+}$. We were unable to estimate the extent of DNA replication or repair following transformation so we cannot distinguish unequivocally between these two possibilities for gene expression. However, we think that the first is inherently unlikely. Moreover, when HPUra was used to restrict DNA replication after transformation of SL11, the proportion of spo spores was greater than $80 \%$ (Table 3). It is difficult to explain the result if it is assumed that the spoVB locus can be expressed in either the mother cell or the forespore. For this locus at least, it seems reasonable to conclude that its expression is required in the mother cell, and only in the mother cell.

The implications of the results are, firstly, that the genomes of both the mother cell and forespore are actively expressed - this confirms the autoradiographic studies of Ryter et al. $(1966 a)$ and Ryter \& Whitehouse (1978) which had shown that both genomes were transcribed - and, secondly, that different genes are active in the two cell types and that these genes are specific for spore formation. In addition, genes are shown to be active in one cell type, the mother cell, so that another cell type, the forespore, can develop into a mature spore. This is a clear indication that endospore formation requires cell-cell interaction. The morphological nature of the process is, in itself, a strong indication of this. The system described here may provide a way to study cell-cell interaction in terms of the expression of specific genes.

In general terms, spo loci are expressed in a dependent sequence or sequences (Balassa, 1969; Waites et al., 1970). The demonstration that different spo loci are expressed in the 
mother cell and in the forespore suggests that each cell type might have its own distinct dependent sequence. The opposed double membrane system that separates mother cell from forespore would aid such compartmentalization. However, the opposed double membrane is not an impenetrable barrier. Thus, the concentration of inorganic ions, notably $\mathrm{Ca}^{2+}$, rises markedly in the forespore from stage III onward (Murrell, 1967). Moreover, organic molecules such as dipicolinic acid and arginine are present in high concentrations in the forespore (Ellar \& Postgate, 1975; Singh et al., 1977), yet some, at least, of the enzymes associated with their biosynthesis are located in the mother cell (Andreoli et al., 1973; Singh et al., 1977). There is clearly biochemical evidence for interaction between the mother cell and forespore.

We have shown that it is possible to transform bacteria in conditions where the bulk of the population is starting to form spores. The transformed bacteria are a small subpopulation whose behaviour is atypical. They are retarded by some $3 \mathrm{~h}$ in their time of escape from HPUra inhibition of sporulation when compared with sporulating cultures of $s p o^{+}$, strains. Presumably the transformed bacteria are latent and start to sporulate later than the rest of the population. Transformation and sporulation are, therefore, probably successive processes, and there is no reason to think that sporulating bacteria are being transformed, nor to dispute the view (Bott \& Wilson, 1968) that sporulation and transformation may be mutually exclusive processes.

We have previously reported a rapid method for constructing multiply marked strains by looking for congression of unselected donor markers in spo spores formed by transforming strains bearing the spoVB91 mutation with spo $^{+}$DNA (Piggot \& de Lencastre, 1978). In the present study we observed congression in all cases where we specifically tested for it (Table 5). Thus the method of strain construction can be extended to all these strains, and presumably to a mutant with any spo mutation provided it yields sufficient numbers of transformant spo spores.

The frequency of congression of $\operatorname{trpC} 2^{+}$in transformant spo spores was similar to that in $s p o^{+}$spores for all asporogenous mutants tested (Table 5). It has been argued that the transformed spo locus replicates prior to segregation of DNA into the mother cell and forespore. The $\operatorname{trpC}$ locus replicates after all the spo loci studied, and so must also have replicated in order to allow chromosome completion. Accepting this, the simplest interpretation of the similarity of congression into transformant $s p o$ and $s p o^{+}$spores is that there is no correlation between the DNA strand into which the selected $s p o^{+}$and unselected $\operatorname{trpC2} 2^{+}$markers integrate. This implies that there can be no distinction by incoming DNA between putative 'old' and 'new' strands of DNA.

We wish to thank Dr J. A. Hoch and Dr P. Schaeffer for kindly providing strains. Herminia de Lencastre was supported in part by a fellowship from the Instituto Gulbenkian de Ciência.

\section{REFERENCES}

Andreoli, A. J., Suehiro, S., Sakiyama, D., TAKemoto, J., Vivanco, E., LaRa, J. C. \& Klute, M. C. (1973). Release and recovery of forespores from Bacillus cereus. Journal of Bacteriology 115, 1159-1166.

BALASSA, G. (1969). Biochemical genetics of bacterial sporulation. I. Unidirectional pleiotropic interactions among genes controlling sporulation in Bacillus subtilis. Molecular and General Genetics 104, 73-103.

BotT, K. F. \& Wilson, G. A. (1968). Metabolic and nutritional factors influencing the develop- ment of competence for transfection of Bacillus subtilis. Bacteriological Reviews 32, 370-378.

Brown, N. C. (1970). 6-(p-Hydroxyphenylazo)uracil: a selective inhibitor of host DNA replication in phage-infected Bacillus subtilis. Proceedings of the National Academy of Sciences of the United States of America 67, 1454-1461.

Brown, N. C. (1971). Inhibition of bacterial DNA replication by 6-( $p$-hydroxyphenylazo)-uracil: differential effect on repair and semiconservative synthesis in Bacillus subtilis. Journal of Molecular Biology 59, 1-16. 
Dawes, I. W., Kay, D. \& Mandelstam, J. (1969). Sporulation in Bacillus subtilis. Establishment of a time scale for the morphological events. Journal of General Microbiology 56, 171-179.

DuBNAU, D. (1976). Genetic transformation of Bacillus subtilis: a review with emphasis on the recombination mechanism. In Microbiology-1976, pp. 14-27. Edited by D. Schlessinger. Washington, D.C.: American Society for Microbiology.

DunN, G., Jefrs, P., MANN, N. H., ToRgersen, D. M. \& Yoúng, M. (1978). The relationship between DNA replication and the induction of sporulation in Bacillus subtilis. Journal of General Microbiology 108, 189-195.

Eaton, M. W. \& Ellar, D. J. (1974). Protein synthesis and breakdown in the mother cell and forespore compartments during spore morphogenesis in Bacillus megaterium. Biochemical Journal 144, 327-337.

EllaR, D. J. \& Postgate, J. A. (1974). Characterisation of forespores isolated from Bacillus megaterium at different stages of development into mature spores. In Spore Research 1973, pp. 21-40. Edited by A. N. Barker, G. W. Gould \& J. Wolf. London: Academic Press.

Firz-James, P. C. \& Young, I. E. (1969). Morphology of sporulation. In The Bacterial Spore, pp. 39-72. Edited by G. W. Gould \& A. Hurst. London: Academic Press.

Fujta, Y., Ramaley, R. \& Freese, E. (1977). Location and properties of glucose dehydrogenase in sporulating cells and spores of Bacillus subtilis. Journal of Bacteriology 132, 282-293.

Giles, K. W. \& MYers, A. (1965). An improved diphenylamine method for the estimation of deoxyribonucleic acid. Nature, London 206, 93.

Hranueli, D., Piggot, P. J. \& Mandelstam, J. (1974). Statistical estimate of the total number of operons specific for Bacillus subtilis sporulation. Journal of Bacteriology 119, 684-690.

JENSEN, R. A. (1968). A biochemical basis for apparent abortive transformation in Bacillus subtilis. Genetics 60, 707-717.

Leighton, T., Khachatourians, G. \& Brown, N. (1975). The role of semiconservative DNA replication in bacterial cell development. In ICNUCLA Symposium of Molecular and Cellular Biology III: DNA Synthesis and its Regulation, pp. 677-687. Edited by M. Goulian, P. Hanawalt \& C. F. Fox. Menlo Park, California: Benjamin.

Mandelstam, J., Sterlini, J. M. \& Kay, D. (1971). Sporulation in Bacillus subtilis. Effect of medium on the form of chromosome replication and on initiation to sporulation in Bacillus subtilis. Biochemical Journal 125, 635-641.

MARMUR, J. (1961). A procedure for the isolation of deoxyribonucleic acid from micro-organisms. Journal of Molecular Biology 3, 208-218.

MURRell, W. G. (1967). The biochemistry of the bacterial endospore. Advances in Microbial Physiology 1, 133-251.

Nester, E. W. \& Stocker, B. A. D. (1963). Biosynthetic latency in early stages of deoxyribonucleic acid transformation in Bacillus subtilis. Journal of Bacteriology 86, 785-796.

Nester, E. W., Schafer, M. \& Lederberg, J. (1963). Gene linkage in DNA transfer: a cluster of genes concerned with aromatic biosynthesis in Bacillus subtilis. Genetics 48, 529-551.

Piggot, P. J. (1973). Mapping of asporogenous mutations of Bacillus subtilis: a minimum estimate of the number of sporulation operons. Journal of Bacteriology 114, 1241-1253.

Piggot, P. J. (1978). Organisation of spo locus expression during sporulation of Bacillus subtilis: evidence for different loci being expressed in the mother cell and in the forespore. In Spores, vol. VII, pp. 122-126. Edited by G. Chambliss \& J. C. Vary. Washington, D.C.: American Society for Microbiology.

Piggot, P. J. \& CoOte, J. G. (1976). Genetic aspects of bacterial endospore formation. Bacteriological Reviews 40, 908-962.

Piggot, P. J. \& Lencastre, H. DE (1978). A rapid method for constructing multiply marked strains of Bacillus subtilis. Journal of General Microbiology 106, 191-194.

Piggot, P. J. \& TAYlor, S. Y. (1977). New types of mutation affecting formation of alkaline phosphatase by Bacillus subtilis in sporulation conditions. Journal of General Microbiology 102, 69-80.

Ramaley, R. F. \& Burden, L. (1970). Replacement sporulation of Bacillus subtilis 168 in a chemically defined medium. Journal of Bacteriology 101, 1-8.

Ryter, A. \& Aubert, J. P. (1969). Étude autoradiographique de la synthèse de l'ADN au cours de la sporulation de Bacillus subtilis. Annales de l'Institut Pasteur 117, 601-611.

RYteR, A. \& Whitehouse, R. (1978). Uracil incorporation in the forespore and the mother cell during spore development in Bacillus subtilis. Autoradiographic electron microscopic study. Archives of Microbiology 118, 27-34.

Ryter, A., Bloom, B. \& Aubert, J. P. (1966a). Localisation intracellulaire des acides ribonucleiques synthetises pendent la sporulation chez Bacillus subtilis. Comptes rendus hebdomadaire des séances de l'Académie de sciences 262, 1305-1307.

Ryter, A., SChaeffer, P. \& Ionesco, H. (1966b). Classification cytclogique, par leur stade de blocage, des mutants de sporulation de Bacillus subtilis Marburg. Annales de l'Institut Pasteur 110, 305-315.

Shibano, Y., Tamura, K., Honjo, M. \& Komano, T. (1978). Effect of 6-(para-hydroxyphenylazo)-uracil on sporulation in Bacillus subtilis. Agricultural and Biological Chemistry 42, 187-189.

Singh, R. P., Setlow, B. \& Setlow, P. (1977). Levels of small molecules and enzymes in the mother cell compartment and the forespore of sporulating Bacillus megaterium. Journal of Bacteriology 130, 1130-1138.

SPIZIZEN, J. (1958). Transformation of biochemically deficient strains of Bacillus subtilis by deoxyribonucleate. Proceedings of the National Academy of Sciences of the United States of America 44, 1072-1078.

WaItes, W. M., Kay, D., Dawes, I. W., Wood, D. A., Warren, S. C. \& Mandelstam, J. (1970). Sporulation in Bacillus subtilis. Correlation of biochemical events with morphological changes in asporogenous mutants. Biochemical Journal 118, 667-676. 